\title{
Keefektifan Model Pembelajaran Teams Games Tournament Berbantu Media Question Card untuk Meningkatkan Pemahaman Tema Kayanya Negeriku
}

\author{
*Ashifa Zulfika Safitri' ${ }^{1}$ M. Arief Budiman², Ari Widyaningrum³
}

${ }^{123}$ Pendidikan Guru Sekolah Dasar, Fakultas Ilmu Pendidikan, Universitas PGRI Semarang, Indonesia

\author{
A R T I C L E I N F O \\ Article history: \\ Received 10 May 2019 \\ Received in revised form \\ 10 June 2019 \\ Accepted 15 July 2019 \\ Available online 29 August \\ 2019 \\ Kata Kunci: \\ team games tournament, \\ question card, pemahaman \\ tematik \\ Keywords: \\ team games tournament, \\ question card, \\ qhematic understanding
}

\begin{abstract}
A B S T R A K
Penelitian ini bertujuan untuk mengetahui keefektifan model pembelajaran teams' games tournament berbantu media question card untuk meningkatkan pemahaman Tema Kayanya Negeriku siswa kelas IV Sekolah Dasar. Jenis penelitian ini adalah penelitian kuantitatif dalam bentuk Pre-Experimental Design dengan One-Group Pretest-Posttest. Populasi yang digunakan adalah siswa kelas IV SD Negeri Proyonanggan 14 yang berjumlah 20 siswa tahun ajaran 2018/2019. Instrumen yang digunakan yang digunakan adalah (1) observasi, (2) tes, dan (3) dokumentasi. Analisis data yang digunakan adalah uji normalitas, uji hipotesis (uji-t), dan uji N-Gain. Uji N-Gain digunakan untuk menghitung kemampuan pemahaman tematik siswa kelas IV. Hasil penelitian menunjukkan bahwa terdapat peningkatan nilai posstest setelah diberi perlakuan dibandingkan nilai pretest sebelum diberikannya perlakuan. Hal tersebut dibuktikan pada analisis uji t hasil belajar dengan nilai thitung sebesar 4,36 dan tabel sebesar 2,022 dengan taraf signifikan $5 \%$. Hasil tersebut menunjukkan bahwa nilai thitung $>$ ttabel
\end{abstract} sehingga dapat disimpulkan bahwa model teams games tournament berbantu media question card efektif digunakan untuk meningkatkan pemahaman tematik siswa kelas IV SD Negeri Proyonanggan 14 Batang. Hal tersebut diperkuat dengan Uji N-Gain yang menyatakan peningkatan pemahaman tematik siswa kelas IV SD Negeri Proyonanggan 14 Batang berada dalam kriteria sedang dengan presentase $80 \%$.

\begin{abstract}
A B S T R A C T
The purpose of this study was to determine the effectiveness of the TGT learning model assisted by the media question card to improve the fourth-grade elementary school students understanding of the Theme of The Richness of My Country. The type of research was quantitative research in the form of Pre-Experimental Design with Pretest-Posttest One-Group. The population was fourth grade students at Proyonanggan 14 Elementary School, amount with 20 students in the 2018/2019 academic year. The instruments were (1) observation, (2) tests, and (3) documentation. The data analyzed by the normality test, hypothesis test (t-test), and $\mathrm{N}$-Gain test. The $\mathrm{N}$-Gain test used to calculate thematic comprehension abilities of fourth grade students. The results showed that there was an enhancement in the posstest after being treated compared with the pretest before giving treatment. This evidenced in the analysis of $t$-test results of learning with a $t_{\text {count }}$ of 4.36 and $t_{\text {table }}$ of 2.022 with a significance level of $5 \%$. These results indicate that the $t_{\text {count }}>t_{\text {table }}$ so that it can be concluded that the media question card-assisted TGT model is effectively used to improve the thematic understanding of fourth grade students of SD Negeri 14 Batang. It reinforced by the N-Gain Test which states the enhancement in thematic understanding of fourth grade students of SD Negeri Proyonanggan 14 Batang in the moderate criteria with a percentage of $80 \%$.
\end{abstract}





\section{Pendahuluan}

Pendidikan merupakan suatu proses yang diperlukan untuk mendapatkan keseimbangan dan kesempurnaan dalam perkembangan individu maupun masyarakat. Penekanan pendidikan dibanding dengan pengajaran terletak pada pembentukan kesadaran dan kepribadian individu atau masyarakat di samping transfer ilmu dan keahlian. (Munirah., 2015) sistem pendidikan di Indonesia dewasa ini tampak ada kesenjangan antara keinginan dan realita. Secara makro dapat dilihat dalam aspek pengelolaan, peran pemerintah dan masyarakat, kurikulum atau materi ajar, pendekatan dan metodologi pembelajaran, sumber daya manusia, lingkungan kampus atau sekolah, dana, dan akreditasi. Kesenjangan dalam sistem pendidikan tersebut disebabkan karena faktor politik, ekonomi, sosial-budaya dan sebagainya yang selalu berubah sesuai dengan perubahan dan perkembangan zaman.

Dengan proses semacam ini suatu bangsa atau negara dapat mewariskan nilai-nilai keagamaan, kebudayaan, pemikiran dan keahlian kepada generasi berikutnya, sehingga mereka betul-betul siap menyongsong masa depan kehidupan bangsa dan negara yang lebih cerah. (Nurkholis, 2013)

Kurikulum merupakan inti dari proses pendidikan. Kurikulum yang saat ini digunakan di negara Indonesia adalah kurikulum 2013. Dalam Kurikulum 2013 pembelajaran tematik merupakan pembelajaran yang diterapkan untuk jenjang pendidikan sekolah dasar. Pembelajaran tematik merupakan pembelajaran bermakna bagi siswa, dan lebih menekankan pada penerapan konsep belajar secara utuh tidak terpisah-pisah sehingga dapat memberikan pengalaman yang bermakna serta memberikan keuntungan bagi siswa, diantaranya: (a) mudah memusatkan perhatian pada suatu tema tertentu; (b) mampu mempelajari pengetahuan dan mengembangkan berbagai kompetensi dasar antar mata pelajaran dalam tema yang sama; (c) pemahaman terhadap materi pelajaran lebih mendalam dan berkesan; (d) kompetensi dasar dapat dikembangkan lebih baik dengan mengaitkan mata pelajaran lain dengan pengalaman pribadi siswa; (e) lebih merasakan manfaat dari belajar karena materi disajikan dalam konteks tema yang jelas; (f) lebih bergairah belajar karena dapat berkomunikasi dalam situasi nyata, untuk memgembangkan suatu kemampuan dalam satu mata pelajaran sekaligus mempelajari mata pelajaran lain; (g) dapat menghemat waktu karena mata pelajaran yang disajikan dapat dipersiapkan sekaligus diberikan dalam dua atau tiga kali pertemuan, sedangkan selebihnya dapat digunakan untuk kegiatan remedial dan pengayaan. (Sukiniarti., 2014)

Berdasarkan wawancara yang telah dilakukan dengan bu Khafidho Khasanah selaku guru kelas IV SD Negeri Proyonanggan 14 Batang terdapat permasalahan terhadap penerapan pembelajaran tematik di kelas IV yaitu masih banyaknya siswa yang merasa bingung dengan penggabungan mata pelajaran yang ditetapkan di pembelajaran tematik. Siswa kurang memahami pembelajaran tematik. Banyak siswa yang belum terbiasa menggunakan pembelajaran tematik karena mata pelajarannya dijadikan satu dan tidak terpisah. Selain itu sosialisasi tentang pembelajaran tematik yang kurang sedangkan guru dituntut untuk memiliki kompetensi yang tinggi. Hal ini membuat nilai siswa banyak yang hanya mendekati KKM.

Guru perlu menerapkan model pembelajaran yang variatif agar siswa dapat bersemangat dan tertarik dalam belajar. Pembelajaran yang menyenangkan dapat dilakukan dengan berbagai cara, salah satunya dengan memilih model pembelajaran yang inovatif. Salah satu model pembelajaran yang inovatif dan dapat membuat siswa antusias dalam pembelajaran adalah model pembelajaran Teams Games Tournament (TGT). Model pembelajaran kooperatif tipe Teams Games Tournament (TGT) salah satu tipe atau model pembelajaran kooperatif yang mudah diterapkan, melibatkan aktivitas seluruh siswa tanpa harus ada perbedaan status, melibatkan peran siswa sebagai tutor sebaya dan mengandung unsur permainan dan penguatan. Keunggulan pembelajaran tipe TGT adalah adanya turnamen akademik dalam proses pembelajaran. Dimana setiap anggota kelompok mewakili kelompoknya untuk melakukan turnamen. (Tarigan : (AP \& Amir, 2018)). (Solihah, 2016) Model pembelajaran TGT merupakan jenis pembelajaran kooperatif yang berkaitan dengan STAD. Dengan model pembelajaran TGT siswa yang pintar diusahakan dapat membantu siswa yang kurang, sedangkan bagi siswa yang relatif sudah menguasai materi diharapkan akan lebih memahami materi yang diajarkan. Model pembelajaran kooperatif tipe Teams Games Tournament (TGT) salah satu tipe atau model pembelajaran kooperatif yang mudah diterapkan, melibatkan aktivitas seluruh siswa tanpa harus ada perbedaan status, melibatkan peran siswa sebagai tutor sebaya dan mengandung unsur permainan dan penguatan (Wisnu D. Yudianto, Kamin Sumardi, 2014).

Selain pemilihan model pembelajaran yang inovatif, pembelajaran yang menyenangkan perlu didukung media pembelajaran yang mendukung. Media pembelajaran yang cocok dan mendukung model pembelajaran TGT adalah media question card (kartu tanya). Media question card sangat mendukung ketika digunakannya model pembelajaran TGT karena dalam model Teams Games Tournament (TGT) terdapat turnamen dimana setiap kelompok mengirimkan perwakilannya untuk melakukan turnamen di meja turnamen dengan cara menjawab pertanyaan yang terdapat di kartu tanya. Oleh karena itu media 
kartu tanya (question card) ini sangat cocok digunakan dalam penerapan model Teams Games Tournament (TGT). (Wisnu D. Yudianto, Kamin Sumardi, 2014)Model pembelajaran kooperatif tipe Teams Games Tournament (TGT) salah satu tipe atau model pembelajaran kooperatif yang mudah diterapkan, melibatkan aktivitas seluruh siswa tanpa harus ada perbedaan status, melibatkan peran siswa sebagai tutor sebaya dan mengandung unsur permainan dan penguatan. Keunggulan pembelajaran tipe TGT adalah adanya turnamen akademik dalam proses pembelajaran. (Solihah, 2016) Model pembelajaran TGT merupakan jenis pembelajaran kooperatif yang berkaitan dengan STAD. Dengan model pembelajaran TGT siswa yang pintar diusahakan dapat membantu siswa yang kurang, sedangkan bagi siswa yang relatif sudah menguasai materi diharapkan akan lebih memahami materi yang diajarkan. Dengan demikian, kegiatan belajar tidak hanya untuk siswa yang berkemampuan tinggi saja tetapi juga milik siswa yang berkemampuan rata-rata dan rendah. Keterlibatan siswa secara aktif dalam proses belajar mengajar tentu saja dapat menciptakan kondisi belajar menjadi lebih menyenangkan. Pemilihan model pembelajaran ini merupakan model pembelajaran alternatif yang menarik dan melibatkan siswa secara aktif, yang pada akhirnya diharapkan dapat meningkatkan hasil belajar matematika siswa. (Susanna, 2018) Model pembelajaran ini dapat meningkatkan kinerja pengajaran guru dan prestasi belajar siswa, serta merupakan suatu kiat, petunjuk, strategi, dan seluruh proses belajar yang dapat mempertajam pemahaman daya ingat, serta belajar sebagai proses yang menyenangkan dan bermakna. Pada penerapan model ini dibutuhkan penguasaan materi yang baik oleh seorang guru dan mampu memfasilitasi siswa dalam memahami dan menerapkan konsep ke dalam suatu contoh dengan baik dan tepat.

Penggunaan media kartu tanya (question card) dapat sangat membantu guru untuk menilai apakah siswa dapat memahami materi yang disajikan. Question card atau kartu tanya berisi pertanyaan seputar materi yang diajarkan, jika siswa dapat menjawab pertanyaan yang ada di kartu tanya tersebut maka siswa dapat memahami materi yang diberikan. Question card merupakan kartu tanya yang berbentuk pesergi panjang dengan ukuran 9,5 $\mathrm{cm}$ x 6,5 cm. Di belakang kartu tersebut ada nomor yang sesuai dengan yang digunakan oleh korektor untuk mengoreksi apakah jawaban yang diberikan oleh tim benar apa tidak terdapat sepasang kartu yang satu berisi pertanyaan dan sepasangnya berisi jawaban dari kartu pertanyaan tersebut.

Berdasarkan uraian di atas maka permasalahan ini perlu diteliti dengan judul "Keefektifan Model Pembelajaran Teams Games Tournament (TGT) Berbantu Media Question Card Untuk Meningkatkan Pemahaman Tema Kayanya Negeriku Siswa Kelas IV Sekolah Dasar".

\section{Metode}

Penelitian ini menggunakan metode penelitian kuantitatif karena dalam melakukan penelitian peneliti menggunakan populasi atau sampel berupa siswa kelas IV. Penelitian ini juga menggunakan instrumen dalam penelitian. Data yang dihasilkan berupa data angka yang disajikan secara statistik.

Desain penelitian yang digunakan yaitu Pre-Experimental Designs (nondesigns) dengan desain penelitian One-Group Pretest-Posttest Design yaitu eksperimen dilakukan hanya menggunakan satu kelas saja tanpa kelas pembanding. Kelas yang digunakan dalam penelitian diberikan pretest sebelum diberikan perlakuan yaitu berupa pembelajaran tematik menggunakan model teams games tournament dengan berbantu media question card.

\section{$\mathbf{O}_{1} \mathbf{X ~ O}_{2}$}

Gambar 1.

One Group Pretest - Posttest Design

Keterangan :

$\mathrm{O}_{1} \quad=$ nilai pretest

$\mathrm{O}_{2} \quad=$ nilai posttest

$\mathrm{X} \quad=$ perlakuan yang diberikan

Teknik pengumpulan data dalam penelitian ini adalah observasi, wawancara, dokumentasi, dan tes. bertujuan untuk mendapatkan informasi tentang kondisi awal siswa serta materi yang akan diajarkan.

Observasi dilakukan untuk memantau proses pembelajaran yang sedang berlangsung di kelas. Observasi siswa difokuskan pada motivasi selama pembelajaran berlangsung. Observasi guru difokuskan pada cara mengajar dengan menggunakan metode pembelajaran. Wawancara dilakukan dengan secara 
langsung untuk memperoleh informasi mengenai permasalahan yang terjadi di kelas IV SD Negeri Proyonanggan 14 Batang. Dokumentasi dalam penelitian ini berupa tugas siswa, daftar nilai siswa serta dokumentasi foto dalam pelaksanaan pembelajaran.

Tes merupakan instrumen alat ukur pengumpulan data dimana siswa mengerjakan soal untuk menilai kemampuan siswa yang mencakup pengetahuan. Tes yang diberikan yaitu pretest dan posttest. Teknik analisis data merupakan cara yang digunakan untuk mengolah data hasil penelitian guna memperoleh kesimpulan. Dalam penelitian kuantitatif, analisis data merupakan kegiatan setelah data dari seluruh responden atau sumber data lain terkumpul (Sugiyono, 2017). Berdasarkan pendapat tersebut maka analisis data dalam penelitian ini dijabarkan sebagai berikut:

\section{Uji normalitas awal}

Uji normalitas pada awal yaitu pada hasil perolehan data dari soal tes yang diperoleh sebelum melaksanakan proses pembelajaran dengan menggunakan model teams games tournament berbantu media question card. Uji ini berfungsi untuk mengetahui apakah data-data tersebut secara normal atau tidak. Untuk mengetahui suatu sampel dari populasi yang ada bisa digunakan uji liliefors. Hipotesis statistika dalam uji normalitas adalah sebagai berikut:

Ho : sampel berasal dari data berdistribusi normal

Ha : sampel berasal dari data berdistribusi tidak normal

\section{Uji normalitas akhir}

Setelah semua perlakuan berhasil diberi tes. Data yang diperoleh dari hasil pengukuran kemudian dianalisis untuk mengetahui apakah hasilnya sesuai yang diharapkan. Untuk mengetahui suatu sampel dari populasi yang ada bisa digunakan uji liliefors. Hipotesis statistika dalam uji normalitas adalah sebagai berikut:

Ho : sampel berasal dari data berdistribusi normal

Ha : sampel berasal dari data berdistribusi tidak normal

\section{Uji Hipotesis}

Sesuai dengan rancarangan penelitian untuk menganalisis data hasil eksperimen menggunakan Uji t. Adapun rumus yang digunakan yaitu:

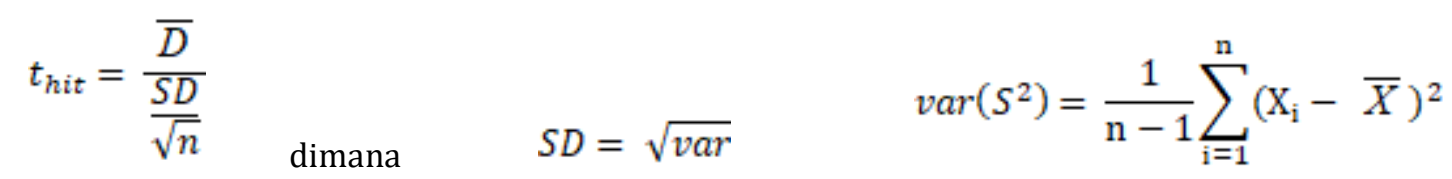

(Montolalu \& Langi, 2018)

Keterangan :

$$
\begin{array}{ll}
\mathrm{t} & =\text { nilai t hitung } \\
\mathrm{D} & =\text { rata-rata selisih pengukuran } 1 \text { (pretest) dan pengukuran } 2 \text { (posttest) } \\
\mathrm{SD} & =\text { standar deviasi selisih pengukuran } 1 \text { (pretest) dan pengukuran } 2 \text { (posttest) }
\end{array}
$$

\section{Uji N-Gain}

Perhitungan nilai rata-rata N-Gain dilakukan untuk melihat peningkatan hasil pemahaman tema Kayanya Negeriku siswa, melihat peningkatan kemampuan siswa, dan memberikan informasi mengenai pecapaian kemampuan siswa. N-Gain dapat dijadikan sebagai data hasil pemahaman tema Kayanya Negeriku siswa setelah penerapan model Teams Games Tournamnet berbantu media question card. Nilai $\mathrm{N}$-Gain ditentukan dengan menggunakan rumus sebagai berikut:

$$
\mathrm{N}-\text { Gain }=\frac{\text { skor posttest-skor pretest }}{\text { skor maks-skor pretest }} \times 100
$$

(Situmorang, Rosdiana Meliana, Muhibbuddin, 2015) 
Tabel 1. Hasil skor Gain Ternormalisasi dibagi dalam tiga kategori

\begin{tabular}{llc}
\hline & Persentase & Klasifikasi \\
\hline $\mathrm{N}$-gain $>70$ & & Tinggi \\
$30 \leq \mathrm{N}$-gain $\leq 70$ & & Sedang \\
$\mathrm{N}$-gain $<30$ & & Rendah \\
\hline & Sumber : Archambault dalam (Situmorang, Rosdiana Meliana, Muhibbuddin, 2015)
\end{tabular}

\section{Hasil dan Pembahasan}

Penelitian ini dilakukan di SD Negeri Proyonanggan 14 Batang. Sebelum melakukan penelitian, peneliti melakukan studi pendahuluan untuk mengetahui permasalahan yang ada di kelas IV dan diperoleh informasi bahwa pembelajaran tematik belum lama diterapkan di sekolah tersebut dan kelas yang menerapkan pembelajaran tematik baru kelas I dan kelas IV. Terdapat permasalahan dalam penerapan pembelajaran tematik di kelas IV yaitu siswa belum begitu menguasai materi pembelajaran tematik, pemahaman siswa dalam pembelajaran tematik masih kurang, dan siswa belum terbiasa dengan model pembalajaran tematik. Metode pembelajaran yang dilakukan oleh guru sudah cukup baik, guru tidak hanya menggunakan metode ceramah, tapi juga menampilkan video pembelajaran guna membantu siswa untuk memahami materi. Namun kegiatan pembelajaran yang dilakukan masih tergolong pasif dan monoton. Karena banyak siswa yang masih belum paham terhadap pembelajaran tematik, maka siswa masih sukar untuk bertanya. Guru yang sering bertanya ke siswa untuk memancing siswa untuk menjawab pertanyaan guru, sehingga siswa hanya berusaha menjawab pertanyaan namun tidak memahami materi pembelajaran yang diajarkan. Hal tersebut membuat pemahaman siswa terhadap pembelajaran tematik masih rendah. Peneliti mempersiapkan rencana pelaksanaan pembelajaran yang akan disertai dengan model pembelajaran teams games tournament berbantu media question card.

Setelah menganalisis hasil uji coba instrumen, peneliti melakukan penelitian di SD Negeri Proyonanggan 14 Batang. Penelitian yang dilakukan di kelas IV dengan jumlah siswa sebanyak 20 siswa. Penelitian dilaksanakan pada tanggal 13 - 16 Mei 2019. Penelitian ini dilakukan dalam empat kali pertemuan. Pengambilan data siswa diperoleh dari nilai pretest dan posttest berupa soal pilihan ganda yang berjumlah 20 soal.

Kelas yang digunakan dalam penelitian diberikan pretest sebelum diberikan perlakuan yaitu berupa pembelajaran tematik menggunakan model teams games tournament dengan berbantu media question card dengan tujuan untuk meningkatkan pemahaman pembelajaran tematik siswa kelas IV. Setelah diberikannya pretest peneliti melakukan posttest untuk mendapatkan hasil belajar sesudah diberikannya perlakuan dengan menggunakan model teams games tournament, sehingga peneliti dapat mengetahui peningkatan kemampuan pemahaman tematik pada siswa kelas IV. Penelitian ini menggunakan instrumen tes berupa soal pilihan ganda.

Pelaksanaan penelitian ini, di awal pertemuan siswa diberikan soal pretest untuk mengetahui hasil belajar siswa sebelum diberikan perlakuan. Pada tahap ini siswa belum diberikan perlakuan oleh peneliti. Selesai mengerjakan pretest siswa baru diberikan perlakuan oleh peneliti. Perlakuan yang diberikan berupa pelaksanaan pembelajaran menggunakan model Teams Games Tournament berbantu media question card. Perlakuan tersebut dilakukan selama 3 kali pertemuan. Di akhir perlakuan diberikan soal posttest untuk mengetahui hasil belajar siswa setelah menerima perlakuan oleh peneliti.

Model pembelajaran team games tournament memiliki keunggulan membuat siswa menjadi lebih berani dalam menyampaikan pendapat dan melatih kerja sama secara diskusi berkelompok. Pembelajaran yang berlangsung secara kooperatif (berkelompok) mempunyai tujuan agar siswa bisa saling bekerja sama dan membantu antar anggota kelompoknya untuk memahami pembelajaran yang diajarkan tanpa membeda-bedakan anggotanya, karena di dalam model pembelajaran kooperatif kerja sama antar tim mempengaruhi hasil belajar. Oleh karena itu penulis memilih sebuah model kooperarif berupa Teams Games Tournament dalam penelitian ini. Pelaksanaan pembelajaran dengan menggunakan model kooperatif Teams Games Tournament ini siswa diajak memahami pembelajaran tematik dengan belajar secara berkelompok dan berturnamen. Pada akhir turnamen setiap tim akan dihitung skor yang diperolehnya sehingga setiap tim akan berkompetisi supaya tim mereka masing-masing bisa menang. Untuk membuat tim menang tentunya diperlukan kerja sama antar anggota tim untuk bisa memahami materi agar timnya bisa mendapatkan skor. Hal ini sejalan dengan tujuan pembelajaran kooperatif yang disampaikan oleh Slavin (Al-Tabany, 2017) belajar kooperatif menekankan pada tujuan dan kesuksesan kelompok, yang hanya dapat dicapai jika semua anggota kelompok mencapai tujuan atau penguasaan materi. 
Model Teams Games Tournamnet sangatlah cocok digunakan untuk membantu siswa dalam memahami materi pembelajaran, dalam pembelajaran siswa dikelompokkan menjadi beberapa tim. Pembelajaran dibuat seolah-olah siswa sedang berada dalam sebuah turnamen. Hal ini tentunya membuat siswa dalam belajar akan meningkat dan pemahaman siswa terhadap materi pembelajaran juga bertambah. Hasil penelitian dengan menggunakan model Teams Games Tournament pada kelas IV menunjukkan kenaikan pada hasil posttest. Perolehan rata-rata hasil nilai posttest meningkat dari ratarata hasil nilai pretest.

Berdasarkan hasil penelitian menunjukan bahwa ada pengaruh terhadap penggunaan model Teams Games Tournament berbantu media question card di SD Negeri Proyonanggan 14 Batang. Hasil belajar sebelum diberikan perlakuan, nilai pretest menunjukkan rata-rata 62,5 terdapat 11 siswa yang belum lulus KKM. Sedangkan hasil belajar setelah diberikan perlakuan, nilai posttest menunjukkan kenaikan rata-rata nilai menjadi 78,5 terdapat 4 siswa yang belum lulus KKM. Hal ini menunjukkan adanya pengaruh terhadap penerapan model Teams Games Tournament berbantu media question card.

Tabel 2. Rekapitulasi Data Hasil Pretest dan Posttest

\begin{tabular}{cccc}
\hline Jenis Tes & Nilai Tertinggi & Nilai Terendah & Rata-rata \\
\hline Pretest & 85 & 35 & 62,5 \\
Posttest & 95 & 60 & 78,5 \\
\hline
\end{tabular}

Berdasarkan Tabel 2 diatas hasil belajar sebelum diberikan perlakuan nilai pretest menunjukan rata-rata sebesar 62,5 terdapat 9 siswa yang sudah mencapai KKM dan 11 siswa belum mencapai KKM. Sedangkan hasil belajar sesudah diberikan perlakuan nilai posttest menunjukan rata-rata sebesar 78,5 terdapat 16 siswa yang sudah mencapai KKM dan 4 siswa yang belum mencapai KKM. Dari hasil nilai pretest dan nilai posttest ini menunjukan bahwa ada peningkatan terhadap hasil pemahaman pembelajaran tematik sesudah diberikan perlakuan dengan kenaikan rata-rata sebesar 16.

\section{Uji-t}

Untuk mengetahui apakah terdapat perbedaan kemampuan pemahaman tematik siswa kelas IV dilakukan melalui uji-t. Berdaasarkan hasil pretest dan posttest siswa kelas IV SD Negeri Proyonanggan 14 Batang tahun ajaran 2018/2019 sebagai subjek penelitian maka diuji hipotesis, untuk menguji perbedaan rata-rata hasil pretest dan posttest digunakan uji t. Hipotesis yang diuji adalah sebagai berikut:

$\mathrm{H}_{0}=t_{\text {hitung }}<\mathrm{t}_{\text {tabel }}$ (pembelajaran tematik dengan menggunakan model teams games tournament berbantu media question card tidak efektif untuk meningkatkan kemampuan pemahaman tematik pada siswa kelas IV SD Negeri Proyonanggan 14 Batang).

$\mathrm{H}_{\mathrm{a}}=\mathrm{t}_{\text {hitung }}>\mathrm{t}_{\text {tabel }}$ (pembelajaran tematik dengan menggunakan model teams games tournament berbantu media question card efektif untuk meningkatkan kemampuan pemahaman tematik pada siswa kelas IV SD Negeri Proyonanggan 14 Batang).

Menurut data hasil pretest dan posttest kemudian dianalisis menggunakan uji t,. Dari data analisis uji t diperoleh thitung $=8,318$ selanjutnya dibandingkan dengan tabel $=2,022$ dengan $\mathrm{db}=40-1$ pada taraf signifikan 5\% hasil ini menunjukkan bahwa $t_{\text {hitung }}>\mathrm{t}_{\text {tabel }}$ yaitu 4,36 $>2,022$ maka Ha diterima dan $\mathrm{H}_{0}$ ditolak, sehingga dapat disimpulkan bahwa model teams games tournamenr berbantu media question card untuk efektif meningkatkan pemahaman tematik siswa kelas IV SD Negeri Proyonanggan 14 Batang.

\section{Uji N-Gain}

Uji N-Gain digunakan untuk mengukur ada atau tidaknya peningkatan pemahaman pembelajaran tematik pada siswa kelas IV SD Negeri Proyonanggan 14 Batang. Tema yang diukur dalam penelitian ini adalah tema Kayanya Negeriku subtema 1 Kekayaan Sumber Energi di Indonesia. Data yang digunakan untuk mengukur uji N-Gain yaitu diperoleh dari pretest yang dilakukan sebelum siswa mendapat perlakuan dan posttest yang dilakukan setelah siswa mendapat perlakuan. Perlakuan yang diberikan berupa penerapan model team games tournamenr berbantu media question card. Berikut ini daftar hasil uji N-Gain dari data yang diperoleh siswa kelas IV SD Negeri Proyonanggan 14 Batang.

Tabel 3. Hasil Uji N-Gain

\begin{tabular}{lccc}
\hline \multicolumn{1}{c}{ Batasan } & Kategori & Frekuensi & Presentase \\
\hline $\mathrm{g}=0,00$ & Tetap & 0 & $0 \%$ \\
$0,00<\mathrm{g}<0,30$ & Rendah & 3 & $15 \%$ \\
$0,30 \leq \mathrm{g}<0,70$ & Sedang & 16 & $80 \%$ \\
\hline
\end{tabular}




\begin{tabular}{|c|c|c|c|}
\hline $0,70 \leq \mathrm{g} \leq 1,00$ & Tinggi & 1 & $5 \%$ \\
\hline & Jumlah & 20 & $100 \%$ \\
\hline
\end{tabular}

Berdasarkan data Tabel 3 di atas diperoleh hasil uji N-Gain melalui pretest dan posttest siswa kelas IV SD Negeri Proyonanggan 14 Batang pada tema Kayanya Negeriku subtema 1 Kekayaan Sumber Energi di Indonesia. Pada kriteria tetap tidak ada, tidak terdapat siswa yang mendapatkan nilai sama terhadap pretest dan posttest. Pada kriteria rendah terdapat tiga siswa dengan presentase 15\%. Kriteria sedang terdapat 16 siswa dengan presentase 80\%. Dan terakhir kriteria tinggi terdapat satu siswa dengan presentase 5\%. Jadi, dapat disimpulkan bahwa efektifitas kemampuan pemahaman pembelajaran tematik dengan tema Kayanya Negeriku subtema Kekayaan Sumber Energi di Indonesia siswa kelas IV SD Ngerei Proyonanggan 14 Batang mayoritas sedang.

Hal ini sejalan dengan Penelitian yang dilakukan oleh Diana dengan judul penelitian Pengaruh Model Teams Games Tournament Didukung Media Realita Terhadap Kemampuan Mengidentifikasi Manfaat Energi Panas Pada Siswa Kelas IV SDN Tamanan Kecamatan Mojoroto Kota Kediri Tahun Ajaran 2014/2015 diperoleh hasil Dapat disimpulkan (1) Penggunaan Model Teams Games Tournament didukung Media Realita berpengaruh terhadap Kemampuan Mengidentifikasi Manfaat Energi Panas Pada Siswa Kelas IV SDN Tamanan Kecamatan Mojoroto Kota Kediri, dengan ketuntasan klasikal mencapai $\geq$ 75\%. (2) Ada perbedaan pengaruh yang sangat signifikan antara penggunaan model Teams Games Tournament didukung media nyata dibanding model Teams Games Tournament didukung media gambar terhadap kemampuan mengidentifikasi manfaat energi panas pada siswa kelas IV SDN Tamanan Kota Kediri dengan keunggulan pada penggunaan model Teams Games Tournaments (TGT) didukung media realita/benda nyata. Dengan perbandingan nilai rerata kelompok eksperimen $87,4>$ nilai rerata kelompok kontrol 75,6 yang didukung dengan tingkat ketuntasan kelompok eksperimen 89,2\% > tingkat ketuntasan kelompok kontrol 60\%.

\section{Simpulan dan Saran}

Berdasarkan hasil penelitian dan pembahasan dalam penelitian ini, dapat dirumuskan proposi umum bahwa pemilihan pendekatan pembelajaran dan minat komputasi siswa sangat penting dalam meningkatkan hasil belajar matematika siswa. Dengan demikian dapat ditarik kesimpulan sebagai berikut Berdasarkan hasil penelitian dan pembahasan dalam penelitian ini dapat disimpulkan bahwa model teams games tournament berbantu media question card efektif untuk meningkatkan pemahaman pembelajaran tematik siswa kelas IV SD Negeri Proyonanggan 14 Batang. Hal ini dibuktikan dengan analisis uji t dimana $t_{\text {hitung }}>\mathrm{t}_{\text {tabel }}$ yaitu 4,36 $>$ 2,022 maka Ha diterima dan $\mathrm{H}_{0}$ ditolak dan analisis uji $\mathrm{N}$-Gain dimana diperoleh hasil N-Gain sebesar 0,42 dengan kategori sedang. Rata-rata nilai pada kelas IV sesudah diberikan perlakuan sebesar 78,5 dengan presentase ketuntasan belajar sebesar 75\% dengan jumlah siswa yang tuntas sebesar 15 siswa yang mencapai ketuntasan hasil belajar dari 20 siswa. Sedangkan sebelum diberikan perlakuan berupa penerapan model pembelajaran Teams Games Tournament dengan berbantu media question card, presentase siswa yang menapai ketuntasan hasil belajar hanya 30\% yaitu hanya terdapat enam siswa yang berhasil tuntas dari 20 siswa. Dengan nilai rata-rata hasil pretest yaitu 62,5.

Berdasarkan hasil penelitian yang telah dilakukan, peneliti dapat memberikan saran-saran sebagai berikut: 1) Model teams games tournament berpengaruh terhadap meningkatkan pemahaman pembelajaran tematik siswa kelas IV sehingga guru dapat menjadikannya sebagai alternatif model pembelajaran yang dapat digunakan untuk meningkatkan pemahaman sisea terhadap pembelajaran tematik. 2) Media question card dapat dimanfaatkan dalam pembelajaran karena dapat membantu menyamakan persepsi siswa dalam memahami materi pelajaran. 3) Hendaknya pembelajaran yang berlangsung selalu melibatkan siswa secara aktif sehingga siswa dapat mengembangkan pengetahuan yang dimilikinya secara maksimal. 4) Hendaknya dalam kegiatan belajar mengajar dibuat secara berkelompok karena pembelajaran yang dilakukan secara berkelompok akan melatih siswa untuk saling bekerjasama dalam tim dan dapat membuat siswa lebih mudah memahami materi.

\section{Daftar Rujukan}

Al-Tabany, T. I. B. (2017). Mendesain Model Pembelajaran Inovatif, Progresif, Dan Kontekstual:Konsep, Landasan, dan Implementasinya pada Kurikulum 2013. Kencana.

AP, N., \& Amir, A. E. K. (2018). Penerapan Model Pembelajaran Kooperatif Tipe Teams Games Tournament Untuk Meningkatkan Hasil Belajar Ips Siswa Sd Inpres 7/83 Pasempe Kabupaten Bone. JIKAP PGSD: Jurnal Ilmiah Ilmu Kependidikan, 2(2), 53. https://doi.org/10.26858/jkp.v2i2.6945 
Munirah. (2015). Sistem Pendidikan di Indonesia: antara keinginan dan realita. Auladuna, 2(2), 233-245.

Nurkholis. (2013). PENDIDIKAN DALAM UPAYA MEMAJUKAN TEKNOLOGI Oleh: Nurkholis Doktor Ilmu Pendidikan, Alumnus Universitas Negeri Jakarta Dosen Luar Biasa Jurusan Tarbiyah STAIN Purwokerto. Jurnal Kependidikan, 1(1), 24-44. file:///C:/Users/Diana/Downloads/530-Article Text1025-1-10-20160318.pdf

Situmorang, Rosdiana Meliana, Muhibbuddin, \& K. (2015). Penerapan Model Pembelajaran Problem Based Learning Untuk Meningkatkan Hasil Belajar Siswa Pada Materi Sistem Ekskresi Manusia. Jurnal Edubio Tropika, 3(2).

Solihah, A. (2016). Pengaruh Model Pembelajaran Teams Games Tournament (TGT) terhadap Hasil Belajar Matematika. Jurnal SAP, 1(1), 45-53.

https://journal.lppmunindra.ac.id/index.php/SAP/article/view/1010/942.

Sugiyono. (2017). Metode Penelitian Kuantitatif, Kualitatif, dan R\&D. Alfabeta.

Sukiniarti. (2014). Kendala Penerapan Pembelajaran Tematik Di Kelas Rendah Sekolah Dasar. Perspektif Ilmu Pendidikan, 28(2).

Susanna, S. (2018). Penerapan Teams Games Tournament (Tgt) Melalui Media Kartu Domino Pada Materi Minyak Bumi Siswa Kelas Xi Man 4 Aceh Besar. Lantanida Journal, 5(2), 93. https://doi.org/10.22373/lj.v5i2.2832

Wisnu D. Yudianto1, Kamin Sumardi2, E. T. B. (2014). MODEL PEMBELAJARAN TEAMS GAMES TOURNAMENT UNTUK MENINGKATKAN HASIL BELAJAR SISWA SMK. Journal of Mechanical Engineering Education, 1(2), 323-330. https://doi.org/10.32884/ideas.v5i4.227

Al-Tabany, T. I. B. (2017). Mendesain Model Pembelajaran Inovatif, Progresif, Dan Kontekstual:Konsep, Landasan, dan Implementasinya pada Kurikulum 2013. Kencana.

AP, N., \& Amir, A. E. K. (2018). Penerapan Model Pembelajaran Kooperatif Tipe Teams Games Tournament Untuk Meningkatkan Hasil Belajar Ips Siswa Sd Inpres 7/83 Pasempe Kabupaten Bone. JIKAP PGSD: Jurnal Ilmiah Ilmu Kependidikan, 2(2), 53. https://doi.org/10.26858/jkp.v2i2.6945

Munirah. (2015). Sistem Pendidikan di Indonesia: antara keinginan dan realita. Auladuna, 2(2), 233-245.

Nurkholis. (2013). PENDIDIKAN DALAM UPAYA MEMAJUKAN TEKNOLOGI Oleh: Nurkholis Doktor Ilmu Pendidikan, Alumnus Universitas Negeri Jakarta Dosen Luar Biasa Jurusan Tarbiyah STAIN Purwokerto. Jurnal Kependidikan, 1(1), 24-44. file:///C:/Users/Diana/Downloads/530-Article Text1025-1-10-20160318.pdf

Situmorang, Rosdiana Meliana, Muhibbuddin, \& K. (2015). Penerapan Model Pembelajaran Problem Based Learning Untuk Meningkatkan Hasil Belajar Siswa Pada Materi Sistem Ekskresi Manusia. Jurnal Edubio Tropika, 3(2).

Solihah, A. (2016). Pengaruh Model Pembelajaran Teams Games Tournament (TGT) terhadap Hasil Belajar Matematika. Jurnal SAP, 1(1), 45-53. https://journal.lppmunindra.ac.id/index.php/SAP/article/view/1010/942.

Sugiyono. (2017). Metode Penelitian Kuantitatif, Kualitatif, dan R\&D. Alfabeta.

Sukiniarti. (2014). Kendala Penerapan Pembelajaran Tematik Di Kelas Rendah Sekolah Dasar. Perspektif Ilmu Pendidikan, 28(2).

Susanna, S. (2018). Penerapan Teams Games Tournament (Tgt) Melalui Media Kartu Domino Pada Materi Minyak Bumi Siswa Kelas Xi Man 4 Aceh Besar. Lantanida Journal, 5(2), 93. https://doi.org/10.22373/lj.v5i2.2832

Wisnu D. Yudianto1, Kamin Sumardi2, E. T. B. (2014). Model Pembelajaran Teams Games Tournament Untuk Meningkatkan Hasil Belajar Siswa SMK. Journal of Mechanical Engineering Education, 1(2), 323-330. https://doi.org/10.32884/ideas.v5i4.227 